\title{
Tree ring-based temperature reconstruction over the past 186 years for the Miyaluo Natural Reserve, western Sichuan Province of China
}

\author{
Zong Shan Li • Guo Hua Liu • Li Gong • Meng Wang • \\ Xiao Chun Wang
}

Received: 10 October 2013 / Accepted: 23 May 2014 / Published online: 12 June 2014

(C) Springer-Verlag Wien 2014

\begin{abstract}
The mountain range of western Sichuan Province of China runs roughly north to south defining the eastern edge of the Tibetan Plateau, where high-resolution climate records are essential for understanding regional climatic phenomena. Unfortunately, instrumental records in this region are too short in duration to confidently gauge the long-term variability of climate change. This paper presented a temperature reconstruction for the western Sichuan Province based on a tree ring width chronology developed from a tree line site $(4,150 \mathrm{~m})$ of the Faxon fir (Abies faxoniana) at the Miyaluo Natural Reserve. This reconstruction, spanning the years from 1824 to 2009 , could account for $46.7 \%$ of the actual variance of annual mean temperature during the calibration period from 1950 to 2002 . The reconstruction could be essentially divided into two distinct subperiods: a relatively cold and stable period in the late nineteenth century and a relatively warm and unstable period in the twentieth century. Years 2001 and 1911 were the warmest $\left(6.32^{\circ} \mathrm{C}\right)$ and coldest $\left(4.87^{\circ} \mathrm{C}\right)$ years in the reconstruction, respectively, while $1960 \mathrm{~s}\left(5.77^{\circ} \mathrm{C}\right)$ and $1980 \mathrm{~s}\left(5.08^{\circ} \mathrm{C}\right)$ were the warmest and coldest ten consecutive years within the past 186 years. Close coupling observed with other temperature proxies (tree rings, ice cores, and glaciers) from surrounding areas emphasized the high degree of confidence in our reconstruction.
\end{abstract}

\footnotetext{
Z. S. Li $\cdot$ G. H. Liu $(\bowtie) \cdot$ L. Gong $\cdot$ M. Wang

State Key Laboratory of Urban and Regional Ecology, Research Center for Eco-Environmental Science, Chinese Academy of Sciences, Beijing 100085, China

e-mail: ghliu@rcees.ac.cn

X. C. Wang

College of Forestry, Northeast Forestry University, 26 Hexing Road,

Harbin 150040, China
}

\section{Introduction}

Knowledge of climate during the past centuries or millennia can offer important information of natural climate variability in a long-term context and aid efforts to anticipate the probability of future episodes (Mann et al. 2008; Kaufman et al. 2009; Oppo et al. 2009; Frank et al. 2010; Büntgen et al. 2011, 2013; Marcott et al. 2013). Developing this understanding is difficult from the lack of widespread instrumental records before the mid twentieth century (Woodhouse et al. 2010; Esper et al. 2012). This necessitates the use of natural climate archives, such as tree rings, to capture information about climate variability on longer timescales (Battipaglia et al. 2010; Fang et al. 2012, 2013; Linan et al. 2012). Tree ring is one of the best sources of proxy data for paleoclimatic study (Fritts 1976; Schweingruber 1996) and represents the most geographically widespread proxy record capable of yielding annually resolved time series over the past several centuries (D'Arrigo et al. 2012; Morellon et al. 2012).

The western Sichuan Province of China is situated between the Sichuan Basin and the Tibetan Plateau and is characterized by high mountains and deep valleys (Liu et al. 1999; Fu et al. 2004; Taylor et al. 2004). It is largely covered by subalpine coniferous forests distributed in the upper stream of the Yangtze River and its tributaries, with the important function of water and soil conservation and headwater conservation (Wang 2004; Pang et al. 2009). The western Sichuan Province ironically has been identified as a key region of past, present, and projected climate change (Qin et al. 2010; Cui et al. 2012; $\mathrm{Li}$ et al. 2012). At the same time, it contains widespread tree line ecotones allowing temperature-sensitive tree ring chronologies to be developed (Körner and Paulsen 2004). Consequently, this region should have great potential for dendroclimatological studies. Unfortunately, tree ring studies in western Sichuan have received surprising little attention by 
comparison with the adjoined Tibetan Plateau (Bräuning 2001; Yang et al. 2003, 2010a, b).

A century-long tree ring chronology that was introduced 24 years ago by Shao and Fan (1999) yielded the earliest tree ring study in west Sichuan. This unique record covered the 1650-1994 period on the basis of living spruce (Picea balfouriana) trees of the Shanuli Mountain and had been included in the regional winter temperature reconstruction. Much progress has recently been made in deriving annually tree ring estimates of climatic fluctuations over the past centuries in this region. For example, Song et al. (2007) found that tree ring data of Abies chensiensis in the Jiuzhaigou Region, northern part of west Sichuan, coincided with recorded mean lowest winter temperature and provided a reconstructed temperature series for the past 255 years. Wu et al. (2008) demonstrated correspondence between summer temperature and latewood density data of Pinus densata in the Jinchuan Region of western Sichuan, which subsequently obtained the history of summer temperature during the past 86 years. Li et al. (2010) demonstrated that diameter growth of Abies faxoniana in the Wolong Natural Reserve of western Sichuan could yield much valuable information for summer temperature, and tree ring record have proven useful in evaluating the temperature variability for the past 159 years. Strong growth response to summer temperature was also detected for the spruce (Picea purpurea) radial growth in the Siguniang Mountain of western Sichuan. This allowed for the extension of the preindustrial meteorological record back into the past 358 years (Cao et al. 2012), which should be the longest reconstructed climate series deduced from tree ring materials in western Sichuan. However, climate variability in past of western Sichuan still remains difficult to depict clearly, mainly due to the limited number of site chronologies.

This paper presents a new tree ring-based temperature reconstruction for western Sichuan spanning the 1824-2009 period. This obtained annually dated record will improve our understanding of regional climatic fluctuations of western Sichuan and further help filling a sizeable gap in spatial coverage of tree ring network for this region. The goal of the present study is to (1) investigate the climatic response of the Faxon fir (A. faxoniana), a widespread coniferous species in western Sichuan, and reconstruct the temperature history during the past 186 years and (2) evaluate the spatial representation of the new series and compare it with nearby climate proxy records.

\section{Materials and methods}

\subsection{Study region}

The study site is situated in the Miyaluo Natural Reserve, western Sichuan Province of China $\left(31.4^{\circ}-31.92^{\circ} \mathrm{N}\right.$, $\left.102.58^{\circ}-103.07^{\circ} \mathrm{E}\right)$ (Fig. 1), belonging to the transition zone from the Chengdu Plain to the Tibetan Plateau (Li 1990; Yin and Liu 2005). High mountains and deep valleys characterize this reserve. The reserve covers an area of approximately 368,800 ha, with elevations ranging from 2,200 to $5,500 \mathrm{~m}$. This reserve is famed for the biggest red leaves scenic spot (species of Acer, Larix, Liriodendron, Betula, etc.) of China and accepted as a biosphere reserve of the network of the Man and Biosphere Program of China in 1998. The studied region

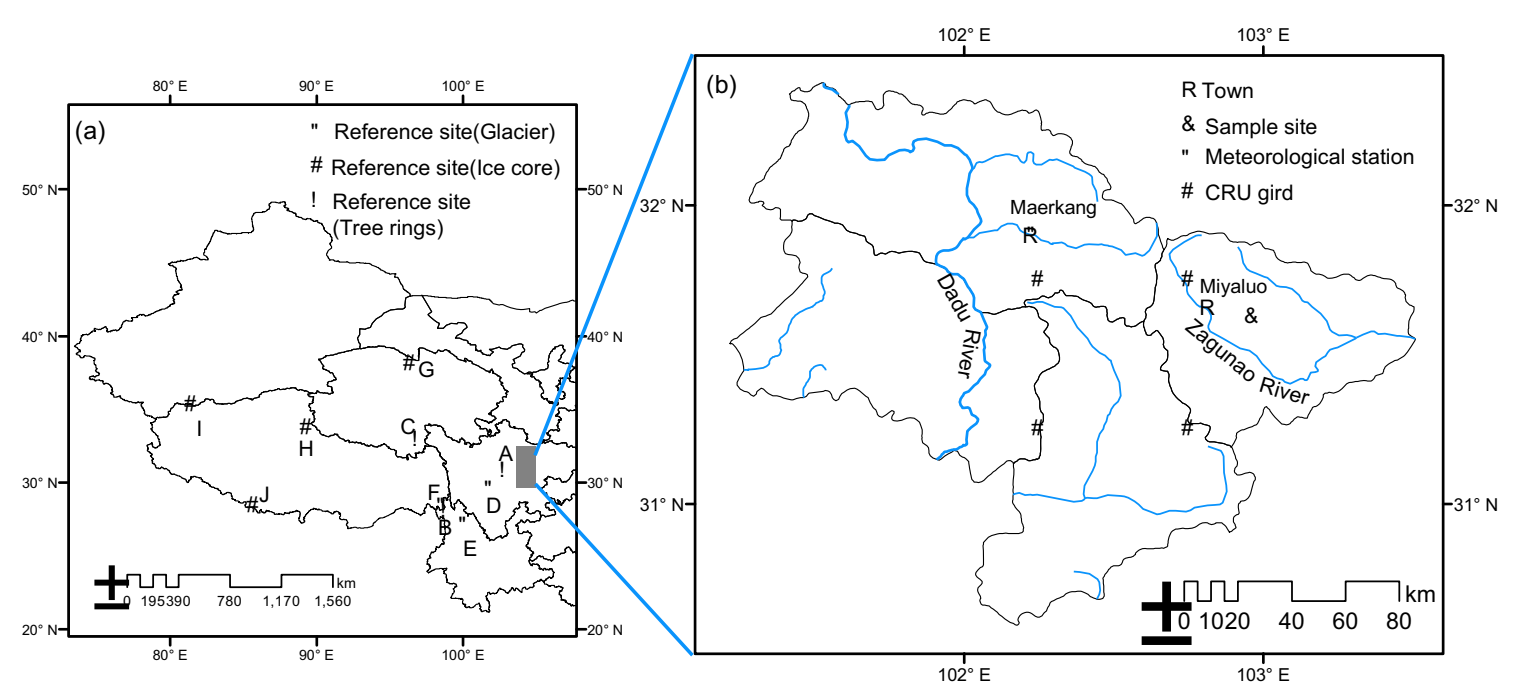

Fig. 1 Location map. a The temperature-sensitive proxies in the surrounding regions. $A$ indicates the temperature reconstruction of the Wolong Natural Reserve; $B$ indicates the temperature reconstruction of the Hengduan Mountains; $C$ indicates the temperature reconstruction of the source region of the Yangtze River; $D$ indicates the Hailuogou Glacier in the Gongga Mountain; $E$ indicates the Baishui No. 1 Glacier of the Jade

Dragon Snow Mountain; $F$ indicates the Mingyong Glacier in the Meili Snow Mountain; $G$ indicates the Dunde ice core; $H$ indicates the Puruogangri ice core; $I$ indicates the Guliya ice core; $J$ indicates the Dasupu ice core. b Locations of tree ring sample site and climate data in this study 
is covered by typical subalpine coniferous forests dominated by the Faxon fir and mixed with Picea likiangensis and Betula albosinensis at the lower elevation (Jiang 1963; Zhang et al. 2005). However, natural coniferous forest of this reserve was felled in large scale during the forest harvesting campaign from the 1930s to the time of 1998. Only about $15 \%$ of natural forest that is not easy to approach, such as the upper tree line zone, was preserved (Liu et al. 2003; Pang et al. 2009). Spruce plantations had been established on most of the harvested areas. Soils that support subalpine coniferous forest are classified as mountain brown dark coniferous forest soils (Chinese Soil Taxonomy), developed from the weathering of metamorphic rock consisted of phyllite, slate, and schist (Taylor et al. 2006).

The climate of this region is characterized by the South Asian monsoon climate, with dry periods from November to April and wet periods from May to October (Sherman et al. 2008). As recorded from the nearby Maerkang meteorological station (Fig. 2), mean annual temperature is $8.66{ }^{\circ} \mathrm{C}$, ranging from $0.56{ }^{\circ} \mathrm{C}$ in January to $16.39{ }^{\circ} \mathrm{C}$ in July. The annual sum of precipitation is $772 \mathrm{~mm}, 88 \%$ of which fall during the summer monsoon season from May to October.

\subsection{Sample and chronology developing}

The Faxon fir chronology was built from trees growing in a tree line site $(4,150 \mathrm{~m})$ at the Jiabi ravine $\left(31.63^{\circ} \mathrm{N}\right.$, $102.96^{\circ}$ E) of Miyaluo Natural Reserve. The sampling was conducted at time of June, 2010, with more than 65 Faxon fir trees being sampled. We collected one sample from each tree at or below $30 \mathrm{~cm}$ near the base of the tree with a Haglof increment borer. To minimize non-climatic influences on tree ring growth and maximize the ages of the sampled trees, only trees with the largest diameter that had no obvious injury or disease were sampled (Fritts 1976). Also, cores were collected parallel to the slope contour to minimize the effects of reaction wood on the growth patterns (Grissino-Mayer 2003).

In the laboratory, the samples were air-dried and then progressively sanded (from 100-grid to 600-grid sandpapers) to make sure the ring boundary is clearly visible and identifiable under a stereoscopic microscope (Orvis and Grissino-Mayer 2002). The tree ring series were cross-dated with skeleton plot and subsequently measured to $\pm 0.001-\mathrm{mm}$ precision using a LINTAB tree ring measurement system. The cross-dating accuracy was verified using the COFECHA program, a software program that uses segmented time series analysis and correlation analyses to determine if ring-width patterns match across samples (Holmes 1983; Grissino-Mayer 2001). In total, 57 cores were crossdated successfully and used for subsequent analysis.

To develop the tree ring chronology, we standardized all cross-dated series to remove age-related growth trends (Fritts 1976) by using the ARSTAN program (Cook and Kairiukstis 1990). ARSTAN computed ring-width indices by dividing the ring-width value by the value computed with conservative methods by fitting a negative exponential curve or a straight line of any slope. A cubic smoothing spline with a $50 \%$ frequency-response cutoff equal to $67 \%$ of the length of the series was also used in a few cases ( 5 out of the 57 cores) when anomalous growth trends occurred (Cook and Peters 1981). We developed the site chronology by averaging the dimensionless indices by computing a biweight robust mean in order to reduce the influence of outliers (Cook and Kairiukstis 1990). We produced two versions of the chronology. The first version is the standard chronology where low-order

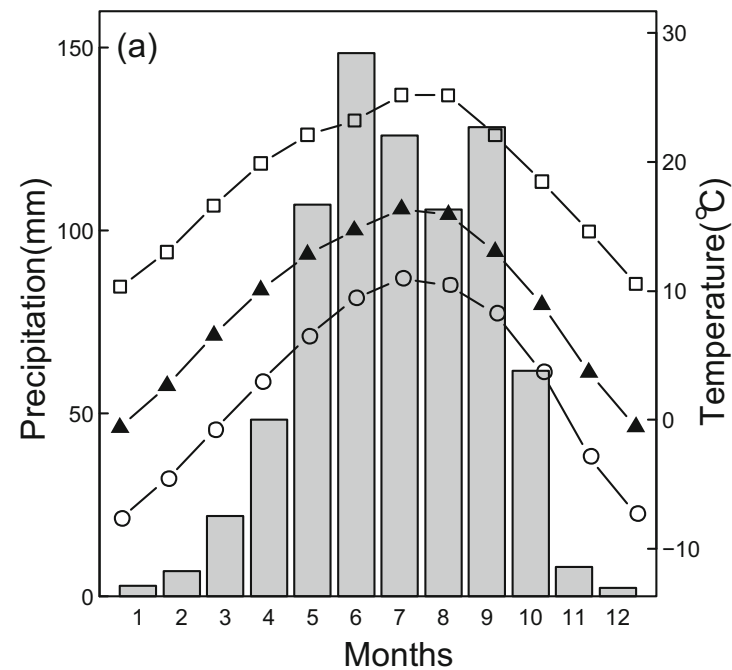

Fig. 2 Monthly variation of total precipitations (bars), mean maximum temperature (line with squares), and mean temperature (line with triangles) and mean minimum temperature (line with circles) for

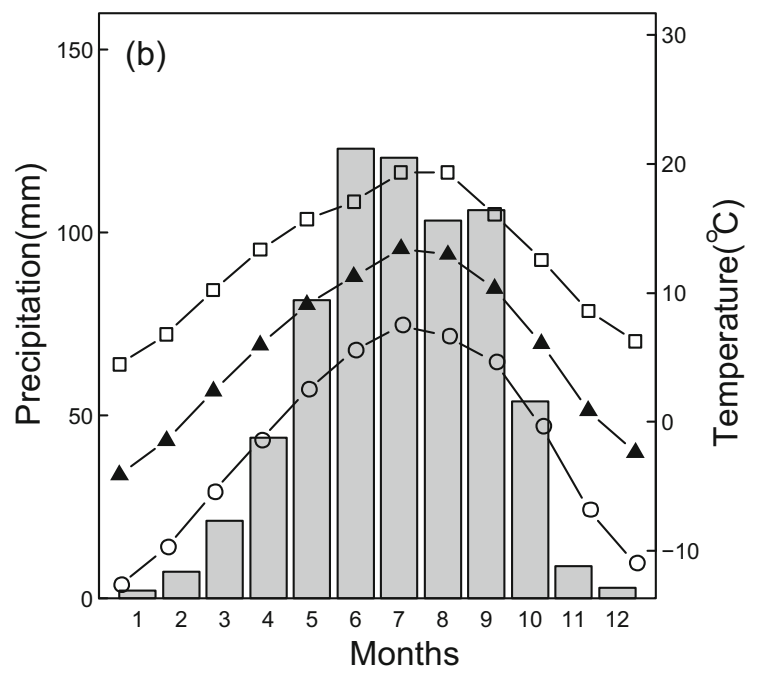

Maerkang meteorological station (a) and CRU gridded grid (b) in Miyaluo forest region of western Sichuan, calculated for the period of 1955-2009 and 1950-2002, respectively 
persistence retained, and this kind of chronology can maximize low-frequency variance potentially due to climate. The second version is the prewhitened or residual chronology where significant low-order persistence and low-frequency signal have been removed and only preserve high-frequency signal (Fritts 1976).

Two descriptive statistics, interseries correlation or Rbar and expressed population signal or EPS, were used to describe the statistical quality of the chronology. Rbar represents the Pearson correlation coefficient among individual series, and EPS indicates how well the site chronology estimates a theoretically infinite population with values exceeding 0.85 generally considered to be reliable (Wigley et al. 1984). Both Rbar and EPS were calculated in a 30-year running window with 15-year overlaps along the chronology. Several other descriptive statistics were also used to gauge the strength of common signal in the chronology, including mean sensitivity (MS), to detect the comparative difference in ring width from one ring to the next and is calculated by averaging the percent change from ring to ring, signal-to-noise ratio (SNR), and variance in the first eigenvector (VFE) to estimate the strength of observed common signals among the trees and first-order autocorrelation (AC1) to detect the level of persistence or autoregression (Fritts 1976).

\subsection{Climate data}

Monthly mean, maximum, and minimum temperatures and precipitation data were obtained from the climate station (the Maerkang station, $31.96^{\circ} \mathrm{N}, 102.24^{\circ} \mathrm{E}, 2,664 \mathrm{~m}$ ) nearby our sample site provided by the China Meteorological Data Sharing Service System (http://cdc.cma.gov.cn/). A database of monthly climate observations on a $0.5^{\circ} \times 0.5^{\circ}$ grid covering the global land surface was constructed by Mitchell and Jones (2005) (CRUts2.1, http://www.cru.uea. ac.uk/). The grid point nearest to our sampling sites (31.75 $\mathrm{N}, 102.75^{\circ} \mathrm{E}$ ) was also used for detecting the growth response to climate conditions. The climate variables included monthly mean, maximum, and minimum temperatures and precipitation data. The climate-growth relationships were examined by computing correlations (Blasing et al. 1984; Biondi and Waikul 2004) between tree ring chronologies and climate data for their common periods: 1954-2009 for the meteorological station and 19502002 for the grid point, respectively. The period analysis was October of the previous year through October of the current year, purposely including the previous growing season due to its influence on current growth (Fritts 1976). Additionally, the CRUTS2-gridded temperature data sets were employed to explore the spatial climate signature of growth variability of our tree ring data. This analysis was performed using the KNMI Climate Explorer (http:// climexp.knmi.nl/).

\section{Results}

\subsection{Chronology statistics}

The standard chronology of Faxon fir spanned the time period from 1824 to 2009, truncated at a minimum sample size of five series (Fig. 3a). The mean segment length, or the average number of rings per core, was 140 years (from 85 to 212 years), a value that set the ceiling for decadal variability retention. The reliable portion of standard chronology extended from 1845 to 2009, with an EPS $>0.85$ (Fig. 3c), and the mean Rbar during this period was 0.586 (Fig. 3b). The EPS threshold corresponded to a sample depth of 17 cores (Fig. 3d). The standard chronology showed a low MS (MS= 0.188 ) indicating a comparatively low interannual variation (Table 1), which was a typical feature for trees in humid environments. The high value of AC1 (0.819) evidently demonstrated that the ring-width data had some autocorrelation that was likely caused by biological feedback (Fritts 1976). The relatively high level of SNR (48.6) and VFE (53.02\%) indicated a high percentage of common variance of the components represented in the standard chronology. The value of $\mathrm{AC} 1$ for residual chronology is near zero, indicating low-order persistence among the trees that had been effectively removed. The values of MS, Rbar, EPS, and VFE for residual chronology are slightly lower than standard chronology, but still demonstrating the signal strength and the intensity of common signals. The values in Table 1 give evidence for a high statistical quality of the standard and residual chronologies obtained, and ring width of Laxon fir is a very sensitive parameter reflecting clearly the signal of exogenous influences.

\subsection{Climate responses of the tree ring chronologies}

The correlations between standard chronology and temperature variables of the meteorological station were in general strongest for April and July (Fig. 4). However, this kind of correlations (positive) was weak and insignificant for minimum temperature. In addition, the magnitudes of positive correlations were also strong for the temperatures (mean and maximum) of September. In contrast, precipitation was only weakly correlated to growth. The chronology had apparently stronger correlations with temperatures of Climatic Research Unit (CRU) grid (Fig. 5) than those of the meteorological station. The chronology showed strong and consistent correlations (positive) with the monthly temperature variables, and the most pronounced correlations were found for April, July, September, and prior December. In comparison to mean and maximum temperatures, minimum temperature had a similar but much weaker correlation pattern with tree rings. Precipitation was less able to explain the annual variations 


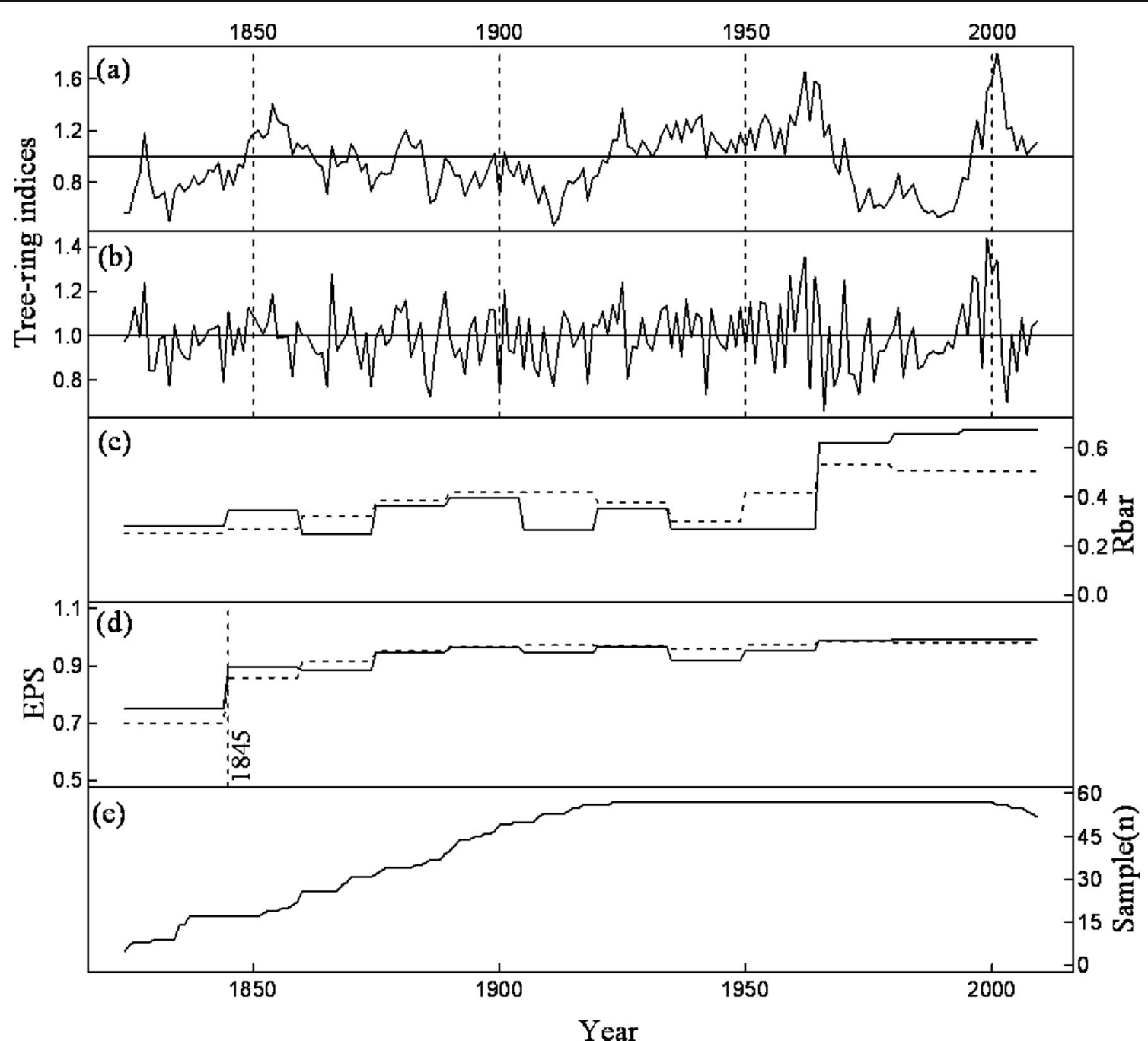

Fig. 3 The standard and residual chronologies of the Laxon fir. a Standard chronology, b residual chronology, $\mathbf{c}$ Rbar, d EPS (vertical dotted line is the year of EPS 0.85 cutoff value), and $\mathbf{e}$ changing sample size over

of tree growth, although relatively strong correlations (negative) were also seen for March and June.

Correlation analysis (Fig. 4) underlined the negative relationships between residual chronology and meteorological temperatures, especially for March and May in spring, which is different from the positive temperature response found for standard chronology. Residual chronology had a uniform positive relationship with temperature data for time. Note that the solid and dashed lines in $\mathbf{c}$ and $\mathbf{d}$ indicate the value for standard and residual chronologies, respectively

CRU grid, but this kind of relationship with temperature is more pronounced for standard chronology (Fig. 5). Residual chronology revealed only weak associations with precipitation both for the meteorological station and CRU grid, and only the negative correlation of May precipitation for CRU grid reached the significant levels. This is similar to the weak precipitation sensitivity found for standard chronology.

Table 1 Site information and statistics of standard and residual tree ring chronologies

\begin{tabular}{|c|c|c|c|c|c|c|c|c|c|c|c|c|}
\hline & Location (Lat./Lon.) & Elev. (m) & Cores/trees & Time span (A.D.) & MSL & AGR (mm) & $\mathrm{SD}(\mathrm{mm})$ & MS & $\mathrm{AC} 1$ & Rbar & EPS & VFE $(\%)$ \\
\hline STD & $\begin{array}{l}102.96^{\circ} \mathrm{E} \\
31.63^{\circ} \mathrm{N}\end{array}$ & 4,150 & $57 / 57$ & 1824-2009 & 140 & 0.529 & 0.263 & 0.188 & 0.819 & 0.714 & 0.98 & 53.02 \\
\hline RES & - & - & - & - & - & - & - & 0.177 & 0.041 & 0.68 & 0.975 & 47.06 \\
\hline
\end{tabular}

STD standard chronology, RES residual chronology, Lat. latitude, Lon. longitude, Elev. elevation, MSL mean segment length, $A G R$ average growth rate, $S D$ standard deviation, $M S$ mean sensitivity, $A C 1$ first-order autocorrelation, Rbar mean interseries correlation, $E P S$ expressed population signal, $V F E$ variance in the first eigenvector 

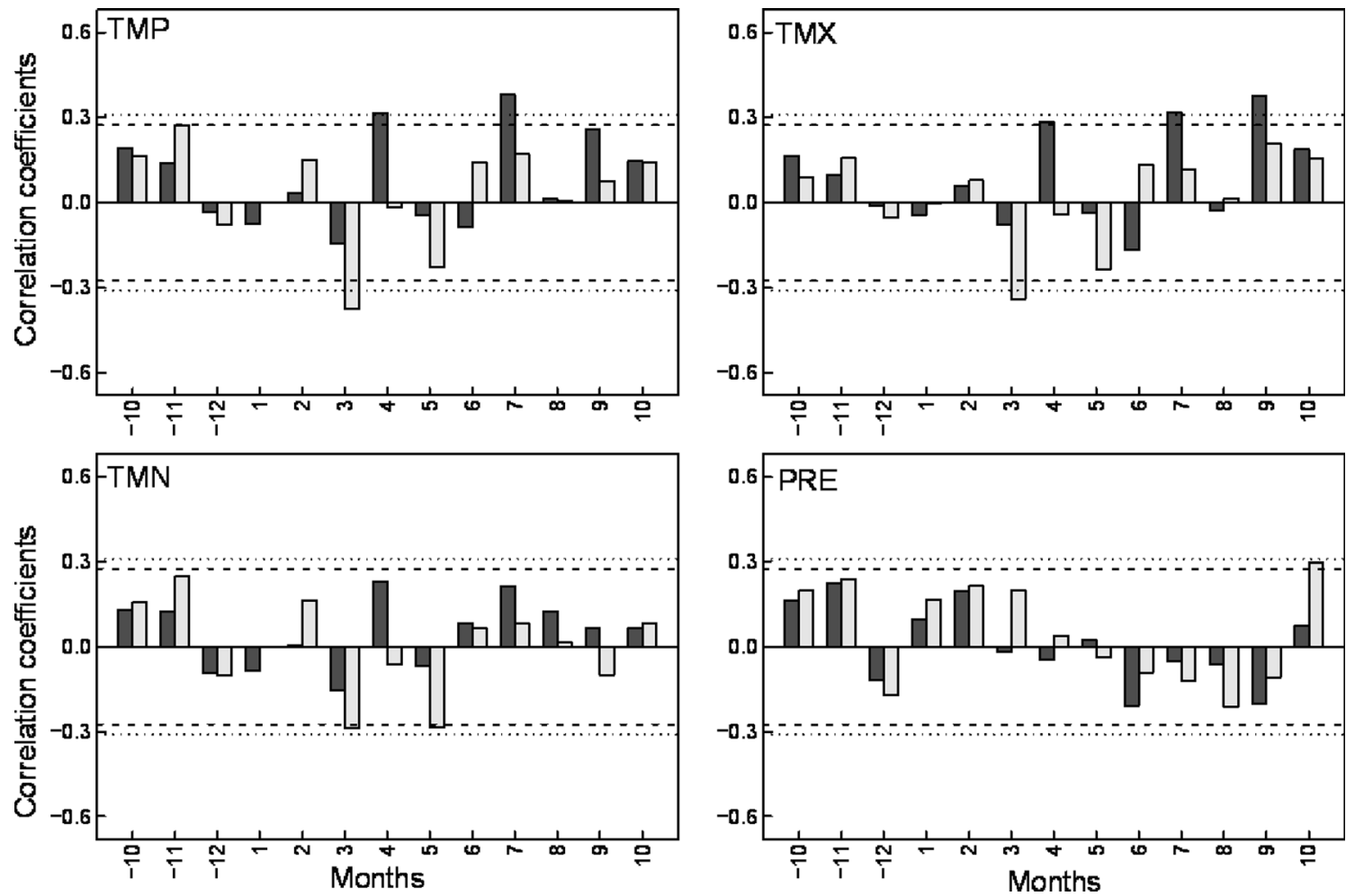

Fig. 4 Correlation analyses between meteorological climate data and the chronology. TMP, TMX, TMN, and PRE are mean temperature, maximum temperature, minimum temperature, and precipitation, respectively.
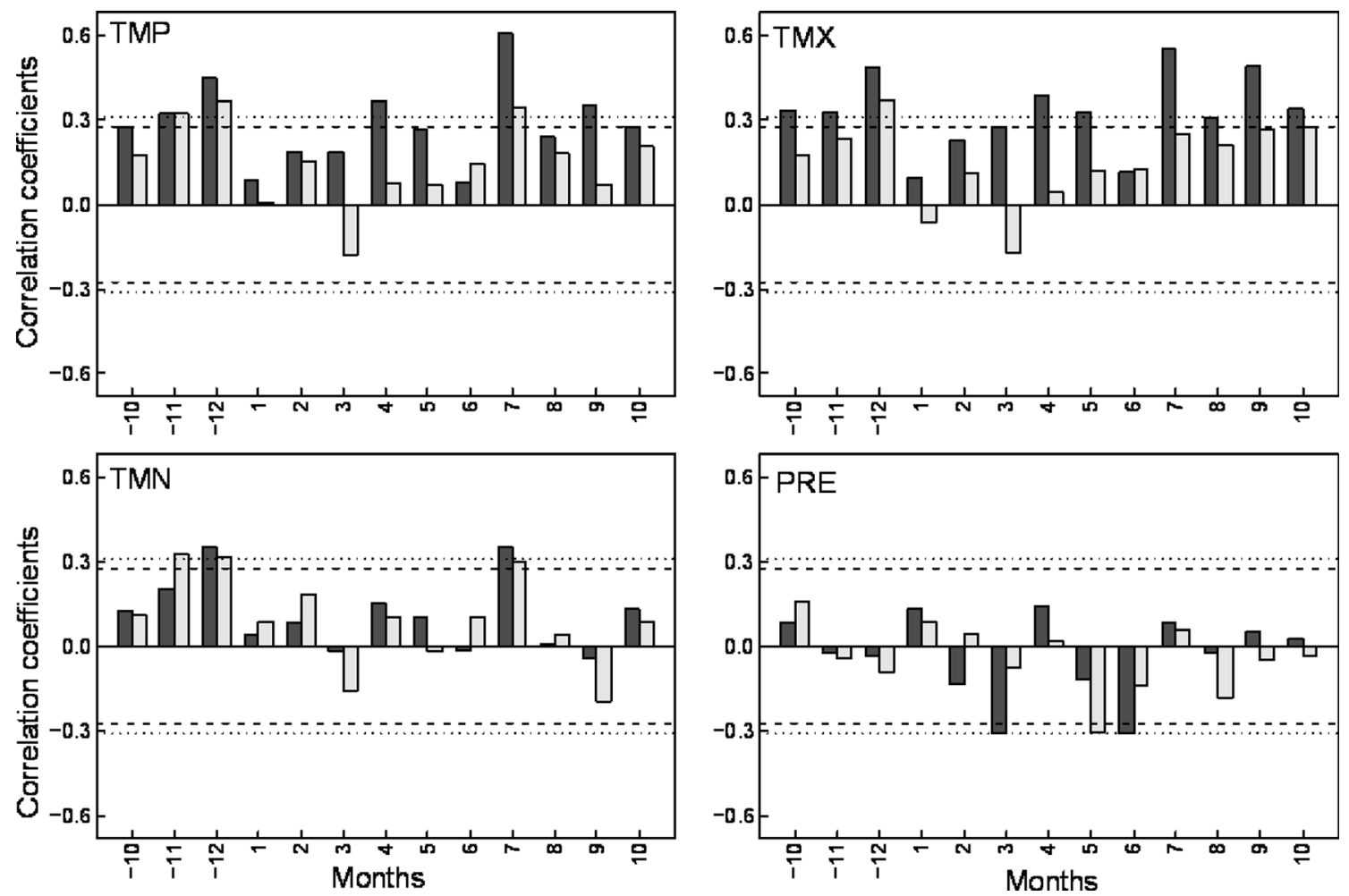

Fig. 5 Correlation analyses between CRU grid climate data and the chronology. TMP, TMX, TMN, and PRE are mean temperature, maximum temperature, minimum temperature, and precipitation, respectively.

The dashed and dotted lines represent significant effects at 95 and $99 \%$ significant levels, respectively 


\subsection{Reconstruction of temperature variations}

Because standard chronology exhibits stronger correlations with temperatures than residual chronology, we selected standard chronology with decadal-scale signal for the issue of temperature reconstruction. The relationships between standard chronology and seasonal groupings of temperature were investigated with correlation analysis. These analyses identified annual mean temperature (CRU grid) as the most appropriate seasonal predict and for reconstruction.

A linear regression model $(Y=1.095 X+4.352)$ was developed (Fig. 6) to reconstruct the temperature history. In the data on tree rings and temperature (1950-2002), the reconstruction accounted for $46.7 \%$ (45.7 \% after adjusted for the loss of degrees of freedom) of the actual temperature variance (Table 2). As shown in Fig. 7a, our reconstruction paralleled the general tendency of the actual temperature during the correlation period. The leave-one-out cross-validation test yielded a positive reduction of error (RE), indicating predictive skill of the regression model. Statistically significant sign test (ST) and product mean test (PMT) between recorded data and leave-one-out-derived estimates were additional indications of the reconstruction's validity. These analyses indicated that this regression model was stable, reliable, and suitable for temperature reconstructions. Utilizing the model above resulted in a temperature reconstruction that covered the past 186 years, spanning the period from 1824 to 2009 (Fig. 7b).

The mean value of this temperature reconstruction was $5.41{ }^{\circ} \mathrm{C}$, and the standard deviation was $0.28{ }^{\circ} \mathrm{C}$. The warm/cold years were defined as temperature was up/below one standard deviation from the mean value, i.e., 5.68 and $5.13{ }^{\circ} \mathrm{C}$, respectively. The number of warm years (29 years)

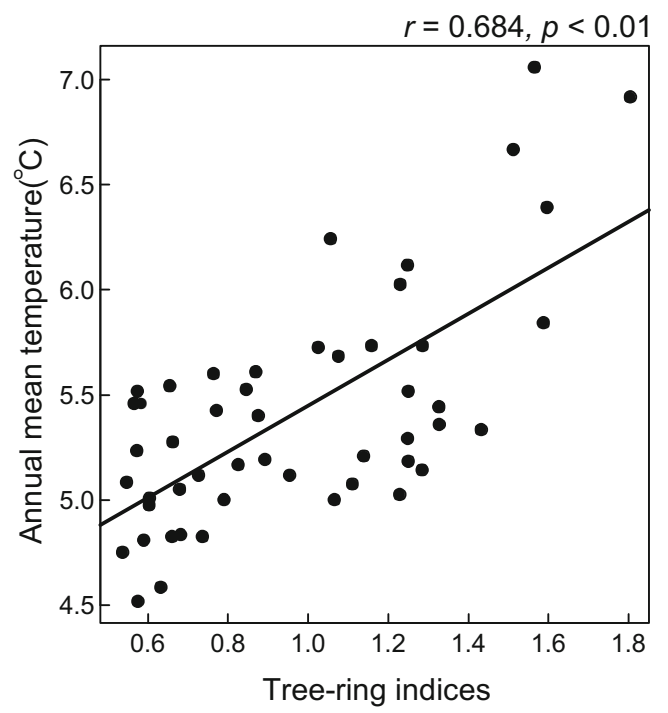

Fig. 6 Scatter plot of instrumental annual mean temperature and tree ring widths with linear relationship highlighted during the period from 1950 to 2002
Table 2 Leave-one-out cross-validation statistics of climate-growth model for climate reconstruction

\begin{tabular}{lllllll}
\hline & $r$ & $r^{2}$ & $r_{\text {adj }}^{2}$ & RE & ST & PMT \\
\hline Calibration & 0.684 & 0.467 & $0.457^{*}$ & - & - & - \\
Verification & 0.634 & $0.433 *$ & $0.42^{*}$ & 0.431 & $37+/ 10-*$ & $4.416^{*}$ \\
\hline
\end{tabular}

$r$ correlation coefficient, $r^{2}$ explained variance, $r_{\text {adj }}^{2}$ adjustment explained variance, $R E$ reduction of error statistic, $S T$ sign test, $P M T$ product mean test

${ }^{*} p<0.01$, significant level

was similar with the number of cold years (32 years), accounted for 15.6 and $17.2 \%$ in the whole reconstruction, respectively. The warm years occurred at the time of 1828 , 1850-1857, 1881, 1925, 1933-1936, 1938-1941, 1943, 1949, 1951, 1953-1955, 1957, 1959-1967, 1997, 19992004, and 2006. Years $2001\left(6.32{ }^{\circ} \mathrm{C}\right), 1962\left(6.17^{\circ} \mathrm{C}\right)$, and $2000\left(6.1^{\circ} \mathrm{C}\right)$ were the three most warm years in the reconstruction. The cold years occurred at the time of 1824-1825, 1830-1831, 1833, 1865, 1886-1887, 1893,1900, 1908, 1910-1913, 1918, 1973-1974, 1976-1979, 1982, and 19851993. Years $1911\left(4.87^{\circ} \mathrm{C}\right), 1833\left(4.9^{\circ} \mathrm{C}\right)$, and $1912\left(4.93^{\circ} \mathrm{C}\right)$ were the three most cold years in the reconstruction.

Fitting a low-pass filter with a $50 \%$ response over 11 years to the reconstruction showed decadal variations and revealed several prolonged warm and cold periods. For instance, the only continuous multi-decadal warm period war from 1921 to 1969 lasted for about half a century. Unusually high temperatures were also showed in the periods of 1847-1866 and 1997-2009. By comparison, the most pronounced cold period occurred during the time of 1885-1920. Other sustained cold episodes were mainly distributed at the time of 1824-1846, 1867-1877, and 1971-1995, respectively. With respect to long-term changes in the regional temperature variability, two stages can be identified in our reconstruction: a relatively stable period in the late nineteenth century and a highly unstable period in the twentieth century.

Spatial correlation analysis substantiated the fact that this reconstructed series could capture the temperature signal on a regional scale (Fig. 8). The strongest correlations emerged highlighted tightly links to the region of western Sichuan. This result demonstrated that our temperature reconstruction can represent climate variations for a large territory in western Sichuan.

\section{Discussion}

4.1 Tree ring growth and climate

It is recognized generally that year-by-year, tree growth of cool and moist sites at high-altitude tree lines displays a strong 

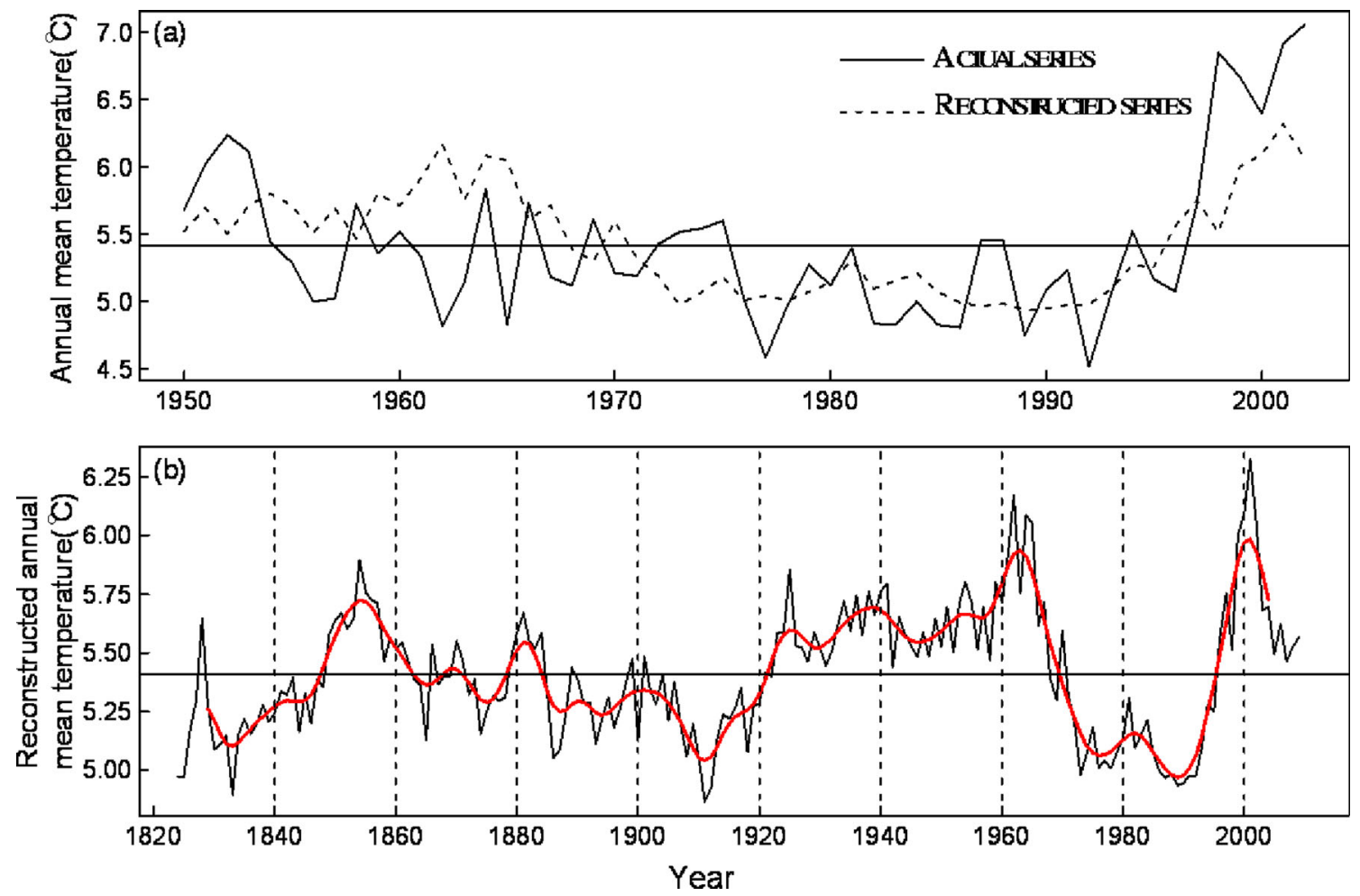

Fig. 7 Climate reconstruction in the Miyaluo Natural Reserve, western Sichuan of China. a The comparison of actual and reconstructed temperatures from 1950 to 2002. b Tree ring reconstruction of annual mean

coherence with local temperature variability (Briffa et al. 1998; Körner and Paulsen 2004). The fidelity of temperature sensitivity, especially for the summer season, has also been

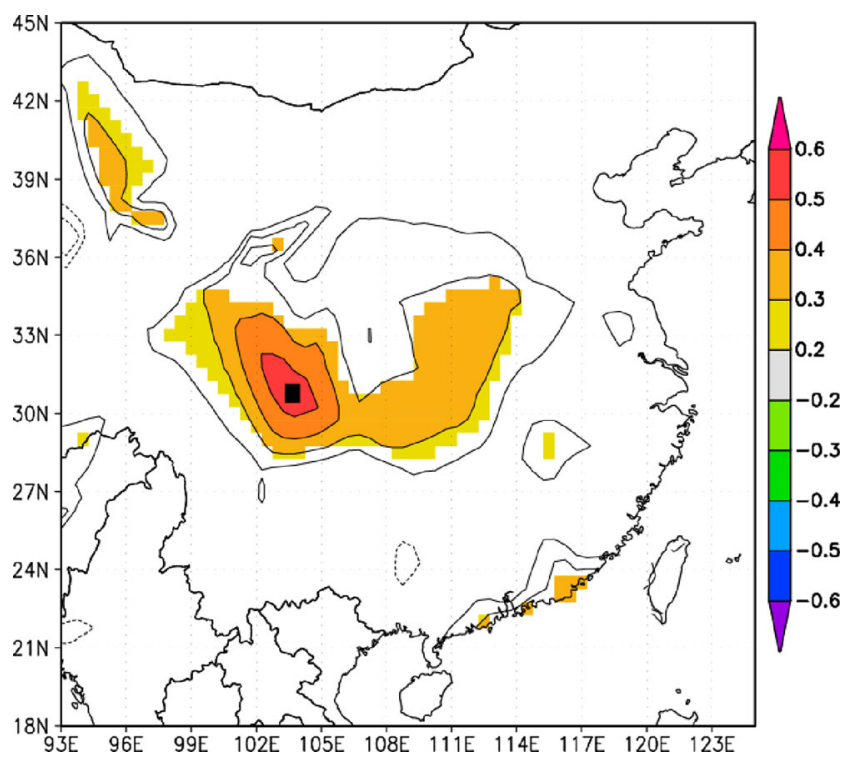

Fig. 8 Spatial correlations of the temperature reconstruction with regional gridded annual mean temperature for the period 1950-2002. The analyses were performed using the KNMI climate explorer (Royal Netherlands Meteorological; http://climexp.knmi.nl/), and the gridded climate dataset was developed by the Climatic Research Unit (Mitchell and Jones 2005; CRUts 2.1). The black box in the figure is the sample site in this study temperature, plotted annually from 1824 to 2009 , along with a smoothed 11-year moving average

clearly demonstrated in tree line sites of the Tibetan Plateau, and the resulted chronologies have been used to reconstruct the past temperature variability (Bräuning and Mantwill 2004; Liang et al. 2008; Fan et al. 2009; Yang et al. 2010a, b; Zhu et al. 2011; Li et al. 2012). In this study, the climatic variables that are most strongly and positively correlated to radial growth are July temperatures in summer season. This is consistent with the claims discussed above. We consider conifer tracheids at tree line divide and enlarge most actively during the warmest condition of the growing season when temperature is a critical factor limiting production and differentiation of xylem cells (Deslauriers et al. 2003; Rossi et al. 2008). Radial growth also exhibits a significant, direct response to September temperatures in autumn season, and this could also be ecophysiologically meaningful. Warm conditions in the autumn season can increase the growing season length and then enrich the storage of carbohydrates and organic substances, the reserves of which are utilized to trigger tree growth in the coming growth season (Fritts 1976). The effect of high autumn temperatures on radial increment has already been described as positive for coniferous trees at the Hengduan Mountain Ranges (Fan et al. 2010) and the northeastern Tibetan Plateau (Gou et al. 2007).

Evidence is accumulating that the minimum temperature, especially in winter season, plays a major role in determining annual growth rates of conifers in the high mountains of the Tibetan Plateau (Bräuning 2001; Gou et al. 2007; Liang et al. 
2008; Fan et al. 2009). The detrimental effect of low winter temperatures on radial width of high-elevation conifers has been interpreted as a consequence of foliar and bud damage, root mortality, frost desiccation, and freezing-induced embolism due to the winter injury events (Hawkins 1993; Auclair et al. 1996; Lazarus et al. 2004). In addition, persistent cold climate of winter can also postpone budburst and cambial reactivation after winter dormancy and thus inhibit growth (Perkins and Adams 1995). In this study, tree growth is effectively more controlled by mean and maximum temperature rather than minimum temperature (Fig. 5). This disagrees with the pattern generally observed in the previous studies. Frost damage has been dismissed as decisive for radial growth of tree species at high elevation, because cold tolerance of those species is generally sufficient to withstand minimum winter temperatures (Sheppard et al. 1989; Körner and Paulsen 2004). In contrast, warm winter climate with high temperatures can modify carbohydrate storage, promote winter photosynthesis, and advance in the timing of the resumption of cambial activity (Fischer and Holl 1991; Lebourgeois et al. 2012). Another explanation could be that roots will continue to grow under the warm winter climate if they have a sufficient supply of nutrients and water. As a result, the tree will have a much larger root structure and will therefore be in a position to grow more during the coming spring (Lebourgeois et al. 2004).

The positive impact of April temperature in spring on tree growth has its biological relevance, as high spring temperatures lead to early breaking of dormancy and the resumption of physiological activity in the tree (Keeling et al. 1996). That is suggestive of an increase in tree growth associated with a lengthening of the active growing season (Myneni et al. 1997). Furthermore, snow melting due to warm spring will provide vital water availability during the early growing season (Groisman et al. 1994; Vaganov et al. 1999). This study suggests that the climatic influence of precipitation upon tree growth is weak and indistinct. This is reasonable because insignificant correlations with precipitation are generally seen from tree rings at high elevation (Körner and Paulsen 2004).

\subsection{Comparison with regional records}

Other temperature-sensitive tree ring records in surrounding regions provide a reference to validate our reconstruction (Fig. 9). Our temperature reconstruction shows significant correlation $(r=0.247, p<0.01$ for $1850-2009)$ with a summer temperature reconstruction from Wolong Natural Reserve of western Sichuan ( $\mathrm{Li}$ et al. 2010). The temperature-sensitive tree ring data of the Hengduan Mountains (Li et al. 2011) also indicate similar decadal scale temperature signals with our reconstruction $(r=0.3, p<0.01$ for $1824-2005)$. The most conspicuous temperature minima in 1824-1846, 1885-1920, and 1971-1995 as reconstructed in our study were also the major cold episodes in the Hengduan Mountains ( $\mathrm{Li}$ et al. 2011). Tree ring data from Jiuzhaigou Natural Reserve of western Sichuan (Song et al. 2007) and Mongolia (D'Arrigo et al. 2001) also show the sustained rate of temperature decrease at the period of $1820 \mathrm{~s}-1840 \mathrm{~s}$. This is concordant with our result. A summer temperature reconstruction for the source region of the Yangtze River (Liang et al. 2008) significantly correlates $(r=0.4, p<0.01)$ with our temperature series for the 1824-1997 period. Pronounced cold spells during the
Fig. 9 Comparisons between the reconstructions in this study with other regional temperature records. All chronologies were smoothed by an 11-year moving average. The comparison data sources are the following: a this study, b Wolong Natural Reserve of western Sichuan ( $\mathrm{Li}$ et al. 2010), c Hengduan Mountains (Li et al. 2011), $\mathbf{d}$ the source region of the Yangtze River (Liang et al. 2008), and e North China (Yi et al. 2012)

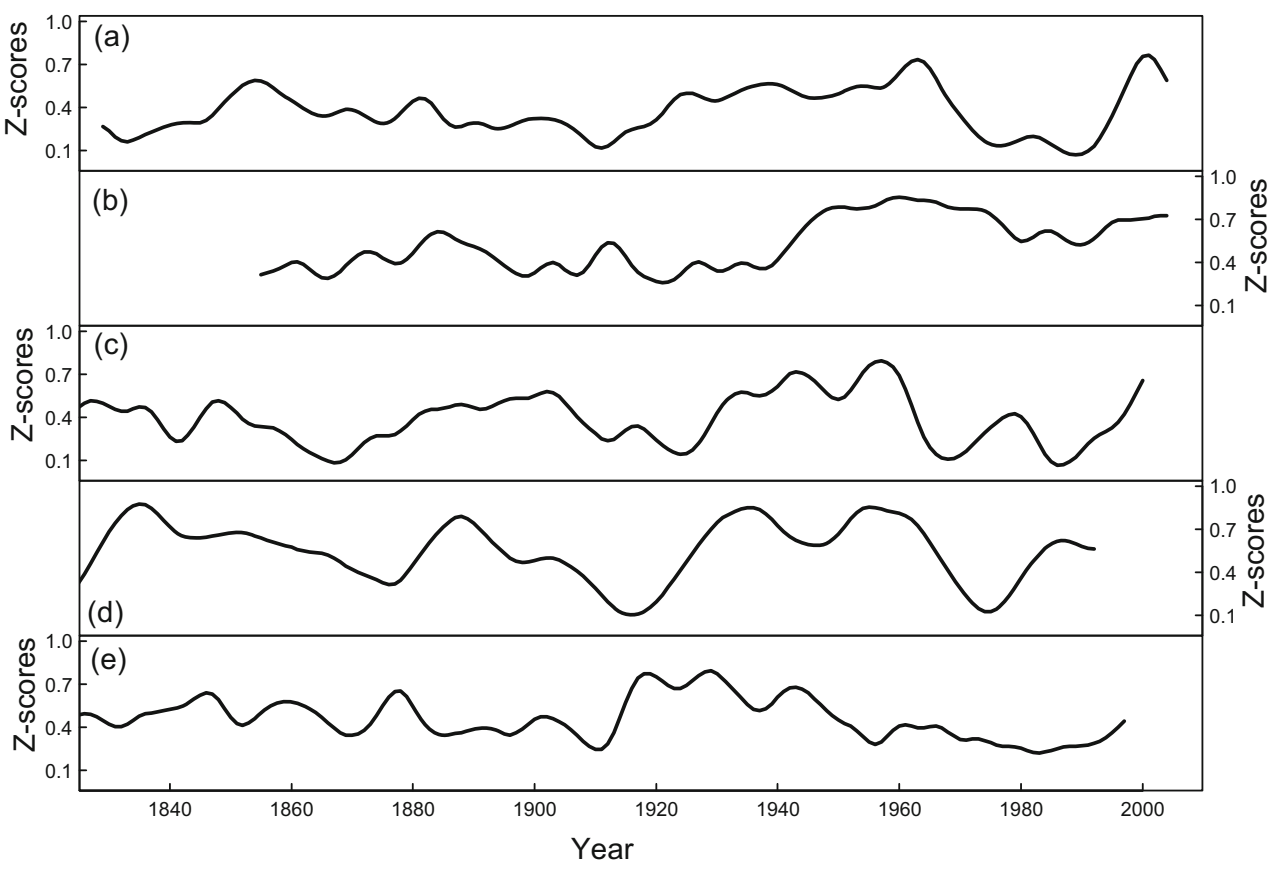


periods of $1860 \mathrm{~s}-1870 \mathrm{~s}, 1900 \mathrm{~s}-1910 \mathrm{~s}, 1970 \mathrm{~s}-1980 \mathrm{~s}$, and peak warming in 1880s-1890s and 1960s-1980s of the source region of the Yangtze River agree with tree ring proxy in this study. Fluctuations in a temperature reconstruction of northcentral China based on historical archives and tree ring records (Yi et al. 2012) are also suggestive for a determined link with our data $(r=0.25, p<0.01)$. One noticeable feature of the temperature series of north-central China is the prolonged warm episode occurring at the period of 1910s-1950s, and the apparently warm climate also appears to be a characteristic pattern in our reconstruction.

The natural fluctuations of monsoonal-temperate glaciers of the Tibetan Plateau are regarded as a reasonable proxy for near-surface air temperatures, especially for summer season (Yang et al. 2003; Yao et al. 2006). Advance and retreat phases of those glaciers can be used to validate the reliability of our reconstruction on a regional scale. The cold period 1820s1840 s as observed in our study is characterized as a cold interval recorded by $\delta^{18} \mathrm{O}$ variation in the ice core recovered from Puruogangri ice field $\left(33.7^{\circ} \mathrm{N}, 88.65^{\circ} \mathrm{E}, 6,200 \mathrm{~m}\right)$ in central Tibetan Plateau and Guliya Glacier $\left(35.17^{\circ} \mathrm{N}, 81.29^{\circ}\right.$ E, 6,200 m) in western Tibetan Plateau (Yao et al. 2006). This cold period is also captured by $\delta^{18} \mathrm{O}$ variation in the ice core recovered by the Dunde Glacier $\left(38.1^{\circ} \mathrm{N}, 96.35^{\circ} \mathrm{E}, 5,325 \mathrm{~m}\right)$ in northeastern Tibetan Plateau but with reductions in cold intensity (Yao et al. 2006). The Hailuogou Glacier $\left(29.59^{\circ} \mathrm{N}\right.$, $101.95^{\circ} \mathrm{E}, 4,880 \mathrm{~m}$ ) in the Gongga Mountain of western Sichuan features a state of advances or standstill during the early twentieth century (1900s-1930s) against a background of cold climate (He et al. 2003). $\delta^{18} \mathrm{O}$ variation in the ice core record from the Malan Glacier $\left(35.83^{\circ} \mathrm{N}, 90.67^{\circ} \mathrm{E}, 5,680 \mathrm{~m}\right)$ in northeastern Tibetan Plateau reveals an apparent cool condition at the late nineteenth century(1880s-1890s) (Wang et al. 2003). The two cold periods above are largely overlapped with the cool interval during 1885-1920 recorded in this study.

The warm period of 1921-1969 recorded in this study is strongly recorded in the nearby monsoon temperate glaciers. For instance, the three major glaciers of the Hengduan Mountains, the Hailuogou Glacier of the Gongga Mountain, the Mingyong Glacier $\left(28.43^{\circ} \mathrm{N}, 98.68^{\circ} \mathrm{E}, 5,000 \mathrm{~m}\right)$ in the Meili Snow Mountain, and the Baishui No. 1 Glacier $\left(27.12^{\circ}\right.$ $\mathrm{N}, 100.2^{\circ} \mathrm{E}, 4,800 \mathrm{~m}$ ) of the Jade Dragon Snow Mountain, all witness the most evident glacier retreats in the 1930s-1960s period since the Little Ice Age (He et al. 2003). The glaciers mentioned above maintain a state of stagnation or speed-down recession in the period 1970s-1980s, then the glaciers tend to retreat in an accelerated rate after the 1990s ( $\mathrm{Li}$ et al. 2009). This is concurrent with the cold period from 1971 to 1995 and warm period from 1997 to 2009 as documented in this study. $\delta^{18} \mathrm{O}$ variations in the four major ice core records of the Tibetan Plateau, Puruogangri, Guliya, Dunde, and Dasupu $\left(28.38^{\circ} \mathrm{N}, 85.72^{\circ} \mathrm{E}, 7,200 \mathrm{~m}\right)$ ice cores, all demonstrate that the climate has gone into a warm period with an exceptionally fast rate about the time of 1920 and then exhibited relatively cooler conditions in the middle of the twentieth century, finally pointed to the unprecedented warmth at the recent decades (Thompson et al. 2000; Yao et al. 2006). These findings parallel the generally observed temperature variation at a multi-decadal timescale in our reconstruction.

\section{Conclusion}

The 186-year annual mean temperature reconstruction for western Sichuan represents an extension and enhancement of the climate record for this region. The mean value of this temperature reconstruction was $5.41{ }^{\circ} \mathrm{C}$, and the standard deviation was $0.28{ }^{\circ} \mathrm{C}$. Years $2001\left(6.32{ }^{\circ} \mathrm{C}\right)$ and 1911 $\left(4.87^{\circ} \mathrm{C}\right)$ were the warmest and coldest years in the reconstruction, respectively. The three warmest episodes in the reconstruction occurring at the intervals were the following: 1921-1969, 1847-1866, and 1997-2009, respectively. Decadal temperature variations were low in these periods of 1885-1920, 1824-1846, 1867-1877, and 1971-1995, respectively. The reconstruction closely matched other tree ring temperature reconstructions from neighboring regions, as well as the fluctuations of several monsoonal temperate glaciers in the Hengduan Mountains Region and ice-core $\delta^{18} \mathrm{O}$ data of the Tibetan Plateau. This demonstrates that the climate information imbedded in tree ring data of this study is representative of temperature variability on regional scale. However, the continuing expansion and development of tree ring networks of western Sichuan are urgently needed to clarify the spatial and temporal details of the historical climate change of this region.

Acknowledgments This research was supported by Natural Science Foundation of China (Grant Nos. 41071039 and 31000210). We greatly thank Hong-Yan Qiu and Cai-Yun Liu of the Tree Ring Laboratory, Institute of Botany, Chinese Academy of Sciences, for the assistance of ring-width measurement. We are also indebted to Yi-He Lv, Xiao-Ming Feng, Li-Xin Lv, and Jin-Long Zhang for providing insightful comments and constructive suggestions for revising an early draft of this article. The study was prompted by the field assistance received from the Institute of Ecology, Sichuan Forestry Research Academy.

\section{References}

Auclair AND, Lill JT, Revenga C (1996) The role of climate variability and global warming in the dieback of Northern Hardwoods. Water Air Soil Pollut 91:163-186

Battipaglia G, Frank D, Büntgen U, Dobrovolny P, Brazdil R, Pfister C, Esper J (2010) Five centuries of Central European temperature extremes reconstructed from tree-ring density and documentary evidence. Global Planet Change 72:182-191 
Biondi F, Waikul K (2004) DENDROCLIM2002: a C++ program for statistical calibration of climate signals in tree-ring chronologies. Comput Geosci-Uk 30:303-311

Blasing TJ, Solomon AM, Duvick DN (1984) Response functions revisited. Tree-Ring Bull 44:1-15

Bräuning A (2001) Climate history of the Tibetan Plateau during the last 1000 years derived from a network of Juniper chronologies. Dendrochronologia 19:127-137

Bräuning A, Mantwill B (2004) Summer temperature and summer monsoon history on the Tibetan plateau during the last 400 years recorded by tree rings. Geophys Res Lett 31:L24205. doi:10.1029/ 2004GL020793

Briffa KR, Schweingruber FH, Jones PD, Osborn TJ, Shiyatov SG, Vaganov EA (1998) Reduced sensitivity of recent treegrowth to temperature at high northern latitudes. Nature 391: $678-682$

Büntgen U, Kyncl T, Ginzler C, Jacks DS, Esper J, Tegel W, Heussner KU, Kyncl J (2013) Filling the Eastern European gap in millenniumlong temperature reconstructions. PNAS 110:1773-1778

Büntgen U, Tegel W, Nicolussi K, McCormick M, Frank D, Trouet V, Kaplan JO, Herzig F, Heussner KU, Wanner H, Luterbacher J, Esper J (2011) 2500 years of European climate variability and human susceptibility. Science 331:578-582

Cao JX, Chen Z, Shang H, Lin B (2012) Tree-ring based average JuneJuly temperature reconstruction for Siguniang Mountains of West Sichuan Plateau, China. J Food Agric Environ 10:1341-1345

Cook ER, Kairiukstis LA (1990) Methods of dendrochronology: applications in the environmental sciences. Kluwer Academic Publishers, dordrecht, Netherlands

Cook ER, Peters K (1981) The smoothing spline: a new approach to standardizing forest interior tree-ring width series for dendroclimatic studies. Tree-Ring Bull 41:45-53

Cui X, Liu S, Wei X (2012) Impacts of forest changes on hydrology: a case study of large watersheds in the upper reaches of Minjiang River watershed in China. Hydrol Earth Syst Sci 16: 4279-4290

D'Arrigo R, Anchukaitis KJ, Buckley B, Cook E, Wilson R (2012) Regional climatic and North Atlantic Oscillation signatures in West Virginia red cedar over the past millennium. Global Planet Chang 84-85:8-13

D’Arrigo R, Jacoby G, Frank D, Pederson N, Cook E, Buckley B, Nachin B, Mijiddorj R, Dugarjav C (2001) 1738 years of Mongolian temperature variability inferred from a tree-ring width chronology of Siberian pine. Geophys Res Lett 28:543-546

Deslauriers A, Morin H, Urbinati C, Carrer M (2003) Daily weather response of balsam fir (Abies balsamea (L.) Mill.) stem radius increment from dendrometer analysis in the boreal forests of Quebec (Canada). Trees 17:477-484

Esper J, Büntgen U, Timonen M, Frank DC (2012) Variability and extremes of northern Scandinavian summer temperatures over the past two millennia. Global Planet Chang 88-89:1-9

Fan ZX, Bräuning A, Tian QH, Yang B, Cao KF (2010) Tree ring recorded May-August temperature variations since $\mathrm{AD} 1585$ in the Gaoligong Mountains, southeastern Tibetan Plateau. Palaeogeogr Palaeoclimatol 296:94-102

Fan ZX, Bräuning A, Yang B, Cao KF (2009) Tree ring density-based summer temperature reconstruction for the central Hengduan Mountains in southern China. Global Planet Chang 65:1-11

Fang KY, Gou XH, Chen FH, Davi N, Liu CZ (2013) Spatiotemporal drought variability for central and eastern Asia over the past seven centuries derived from tree-ring based reconstructions. Q Int 283: $107-116$

Fang KY, Gou XH, Chen FH, Liu CZ, Davi N, Li JB, Zhao ZQ, Li YJ (2012) Tree-ring based reconstruction of drought variability (16152009) in the Kongtong Mountain area, northern China. Global Planet Chang 80-81:190-197
Fischer C, Holl W (1991) Food reserves of scots pine (Pinus sylvestris L).1. Seasonal changes in the carbohydrate and fat reserves of pine needles. Trees 5:187-195

Frank DC, Esper J, Raible CC, Buntgen U, Trouet V, Stocker B, Joos F (2010) Ensemble reconstruction constraints on the global carbon cycle sensitivity to climate. Nature 463:527-U143

Fritts HC (1976) Tree rings and climate. Academic Press, New York

Fu BJ, Wang KL, Lu YH, Liu SL, Ma KM, Chen LD, Liu GH (2004) Entangling the complexity of protected area management: the case of Wolong Biosphere Reserve, southwestern China. Environ Manag 33:788-798

Gou XH, Chen FH, Jacoby G, Cook E, Yang MX, Peng HF, Zhang Y (2007) Rapid tree growth with respect to the last 400 years in response to climate warming, northeastern Tibetan Plateau. Int $\mathrm{J}$ Climatol 27:1497-1503

Grissino-Mayer HD (2001) Evaluating crossdating accuracy: a manual and tutorial for the computer program COFECHA. Tree-Ring Res 57:205-221

Grissino-Mayer HD (2003) A manual and tutorial for the proper use of an increment borer. Tree-Ring Res 59:63-79

Groisman PY, Karl TR, Knight RW (1994) Observed impact of snow cover on the heat-balance and the rise of continental spring temperatures. Science 263:198-200

Hawkins BJ (1993) Photoperiod and night frost influence on the frost hardness of Chamaecyparis nootkatensis. Can J Forest Res 23: $1408-1414$

He YQ, Zhang ZL, Yao TD, Chen T, Pang HX, Zhang D (2003) Modern changes of the climate and glaciers in China's monsoonal temperateglacier region. Acta Geogr Sin 58:551-558 (in Chinese with English abstract)

Holmes RL (1983) Computer-assisted quality control in tree-ring dating and measurement. Tree-Ring Bull 43:69-78

Jiang YX (1963) A initial study on habitat types of Miyaluo and Maerkang alpine in western Sichuan, China. Sci Silver Sin 8:321335 (in Chinese with English abstract)

Kaufman DS, Schneider DP, McKay NP, Ammann CM, Bradley RS, Briffa KR, Miller GH, Otto-Bliesner BL, Overpeck JT, Vinther BM, Members ALkP (2009) Recent warming reverses long-term arctic cooling. Science 325:1236-1239

Keeling CD, Chin JFS, Whorf TP (1996) Increased activity of northern vegetation inferred from atmospheric $\mathrm{CO}_{2}$ measurements. Nature 382:146-149

Körner C, Paulsen J (2004) A world-wide study of high altitude treeline temperatures. J Biogeogr 31:713-732

Lazarus BE, Schaberg PG, DeHayes DH, Hawley GJ (2004) Severe red spruce winter injury in 2003 creates unusual ecological event in the northeastern United States. Can J Forest Res 34: $1784-1788$

Lebourgeois F, Cousseau G, Ducos Y (2004) Climate-tree-growth relationships of Quercus petraea Mill. stand in the Forest of Berce ("Futaie des Clos, Sarthe, France). Ann Forest Sci 61:361-372

Lebourgeois F, Merian P, Courdier F, Ladier J, Dreyfus P (2012) Instability of climate signal in tree-ring width in Mediterranean mountains: a multi-species analysis. Trees 26:715-729

Li CB (1990) Ecological study of Sichuan forest. Sichuan Science and Technology Press, Chengdu (in Chinese)

Li ZS, He YQ, Wang SJ, Jia WX, He XZ, Zhang NL, Zhu GF, $\mathrm{Pu}$ T, Du JK, Xin HJ (2009) Changes of some monsoonal temperature glaciers in Hengudan Mountains Region during 1900-2007. Acta Geogr Sin 64:1319-1330 (in Chinese with English abstract)

Li ZS, Liu GH, Zhang QB, Hu CJ, Luo SZ, Liu XL, He F (2010) Tree ring reconstruction of summer temperature variations over the past 159 years in Wolong National Natural Reserve, western Sichuan, China. Chin J Plant Ecol 34:628-641 (in Chinese with English abstract) 
Li ZS, Shi CM, Liu YB, Zhang JL, Zhang QB, Ma KP (2011) Summer mean temperature variation from 1710-2005 inferred from tree-ring data of the Baimang Snow Mountains, northwestern Yunnan, China. Clim Res 47:207-218

Li ZS, Zhang QB, Ma KP (2012) Tree-ring reconstruction of summer temperature for A.D. 1475-2003 in the central Hengduan Mountains, Northwestern Yunnan, China. Clim Chang 110:455467

Liang EY, Shao XM, Qin NS (2008) Tree-ring based summer temperature reconstruction for the source region of the Yangtze River on the Tibetan Plateau. Global Planet Chang 61:313-320

Linan ID, Buntgen U, Gonzalez-Rouco F, Zorita E, Montavez JP, GomezNavarro JJ, Brunet M, Heinrich I, Helle G, Gutierrez E (2012) Estimating 750 years of temperature variations and uncertainties in the Pyrenees by tree-ring reconstructions and climate simulations. Clim Past 8:919-933

Liu JG, Ouyang Z, Taylor WW, Groop R, Tan KC, Zhang HM (1999) A framework for evaluating the effects of human factors on wildlife habitat: the case of giant pandas. Conserv Biol 13:1360-1370

Liu Q, Yin HJ, Wu Y (2003) A study on the structure of Picea asperata community of Miyaluo subalpine in western Sichuan, China. J Mt Sci 21:695-701

Mann ME, Zhang ZH, Hughes MK, Bradley RS, Miller SK, Rutherford S, Ni FB (2008) Proxy-based reconstructions of hemispheric and global surface temperature variations over the past two millennia. PNAS 105:13252-13257

Marcott SA, Shakun JD, Clark PU, Mix AC (2013) A reconstruction of regional and global temperature for the past 11,300 years. Science 339:1198-1201

Mitchell TD, Jones PD (2005) An improved method of constructing a database of monthly climate observations and associated highresolution grids. Int J Climatol 25:693-712

Morellon M, Perez-Sanz A, Corella JP, Buntgen U, Catalan J, GonzalezSamperiz P, Gonzalez-Trueba JJ, Lopez-Saez JA, Moreno A, PlaRabes S, Saz-Sanchez MA, Scussolini P, Serrano E, Steinhilber F, Stefanova V, Vegas-Vilarrubia T, Valero-Garces B (2012) A multiproxy perspective on millennium-long climate variability in the Southern Pyrenees. Clim Past 8:683-700

Myneni RB, Keeling CD, Tucker CJ, Asrar G, Nemani RR (1997) Increased plant growth in the northern high latitudes from 1981 to 1991. Nature 386:698-702

Oppo DW, Rosenthal Y, Linsley BK (2009) 2,000-year-long temperature and hydrology reconstructions from the Indo-Pacific warm pool. Nature 460:1113-1116

Orvis KH, Grissino-Mayer HD (2002) Standardizing the reporting of abrasive papers used to surface tree-ring samples. Tree-Ring Res 58:47-50

Pang X, Ning WQL, Bao W (2009) The relation among soil microorganism, enzyme activity and soil nutrients under subalpine coniferous forest in Western Sichuan. Acta Ecol Sin 29:286-292 (in Chinese with English abstract)

Perkins TD, Adams GT (1995) Rapid freezing induces winter injury symptomatology in red spruce foliage. Tree Physiol 15: 259-266

Qin NX, Chen X, Fu GB, Zhai JQ, Xue XW (2010) Precipitation and temperature trends for the Southwest China: 1960-2007. Hydrol Process 24:3733-3744

Rossi S, Deslauriers A, Gricar J, Seo JW, Rathgeber CBK, Anfodillo T, Morin H, Levanic T, Oven P, Jalkanen R (2008) Critical temperatures for xylogenesis in conifers of cold climates. Global Ecol Biogeogr 17:696-707

Schweingruber FH (1996) Tree rings and environment. Dendroecology, Haupt, Bern

Shao XM, Fan JM (1999) Past climate on west Sichuan Plateau as reconstructed from ring-widths of Dragon Spruce. Q Sci 1:81-89 (in Chinese with English abstract)
Sheppard LJ, Smith RI, Cannell MGR (1989) Frost hardiness of Picea rubens growing in spruce decline regions of the Appalachians. Tree Physiol 5:25-37

Sherman R, Mullen R, Haomin L, Zhendong F, Yi W (2008) Spatial patterns of plant diversity and communities in Alpine ecosystems of the Hengduan Mountains, Northwest Yunnan, China. J Plant EcolUk 1:117-136

Song HM, Liu Y, Ni WM, Cai QF, Sun JY, Ge WB, Xiao WY (2007) Winter mean lowest temperature derived from tree-ring with in Jiuzhaigou region, China since 1750 A. D. Q Sci 27:486-491 (in Chinese with English abstract)

Taylor AH, Huang JY, Zhou SQ (2004) Canopy tree development and undergrowth bamboo dynamics in old-growth Abies-Betula forests in Southwestern China: a 12-year study. Forest Ecol Manage 200: $347-360$

Taylor AH, Jang SW, Zhao LJ, Liang CP, Miao CJ, Huang JY (2006) Regeneration patterns and tree species coexistence in old-growth Abies-Picea forests in southwestern China. Forest Ecol Manag 223: 303-317

Thompson LG, Yao T, Mosley-Thompson E, Davis ME, Henderson KA, Lin PN (2000) A high-resolution millennial record of the South Asian Monsoon from Himalayan ice cores. Science 289:1916-1919

Vaganov EA, Hughes MK, Kirdyanov AV, Schweingruber FH, Silkin PP (1999) Influence of snowfall and melt timing on tree growth in subarctic Eurasia. Nature 400:149-151

Wang KY (2004) Processes of subalpine forest ecosystem in the west of Sichuan. Sichuan Publishing House of Science and Technology, Chengdu, China (in Chinese)

Wang NL, Yao TD, Pu JC, Zhang YL, Sun WZ, Wang YQ (2003) Temperature history during the past century inferred from Malan ice core of the Tibetan Plateau. Chin Sci Bull 48:1219-12223

Wigley TML, Briffa KR, Jones PD (1984) On the average value of correlated time-series, with applications in dendroclimatology and hydrometeorology. J Clim Appl Meteorol 23:201-213

Woodhouse CA, Meko DM, MacDonald GM, Stahle DW, Cooke ER (2010) A 1,200-year perspective of 21st century drought in southwestern North America. PNAS 107:21283-21288

Wu P, Wang LL, Shao XM (2008) Reconstruction of summer temperature variation from maximum density of alpine pine during 1917-2002 for west Sichuan Plateau, China. J Geogr Sci 18:201-210

Yang B, Bräuning A, Shi YF (2003) Late Holocene temperature fluctuations on the Tibetan Plateau. Q Sci Rev 22:2335-2344

Yang B, Kang XC, Bräuning A, Liu J, Qin C, Liu JJ (2010a) A 622-year regional temperature history of southeast Tibet derived from tree rings. The Holocene 20:181-190

Yang B, Qin C, Huang K, Fan ZX, Liu JJ (2010b) Spatial and temporal patterns of variations in tree growth over the northeastern Tibetan Plateau during the period ad 1450-2001. The Holocene 20: $1235-1245$

Yao TD, Qin DH, Xu BQ, Yang MX, Duan KQ, Wang NL, Wang YQ, Hou SG (2006) Temperature change over the past millennium recorded in ice cores from the Tibetan Plateau. Adv Clim Chang Res 2:99-103 (in Chinese with English abstract)

Yi L, Yu HJ, Ge JY, Lai ZP, Xu XY, Qin L, Peng SZ (2012) Reconstructions of annual summer precipitation and temperature in north-central China since $1470 \mathrm{AD}$ based on drought/flood index and tree-ring records. Clim Chang 110:469-498

Yin HJ, Liu Q (2005) Seed rain and soil seed banks of Picea asperata in subalpine spruce forests, western Sichuan, China. Acta Phytoeco Sin 29:108-115 (in Chinese with English abstract)

Zhang YD, Zhao CM, Liu SR (2005) The influence factors of sub-apline forest restoration in Miyaluo, west Sichuan. Sci Silver Sin 41:189 193 (in Chinese with English abstract)

Zhu HF, Shao XM, Yin ZY, Huang L (2011) Early summer temperature reconstruction in the eastern Tibetan plateau since ad 1440 using tree-ring width of Sabina tibetica. Theor Appl Climatol 106:45-53 